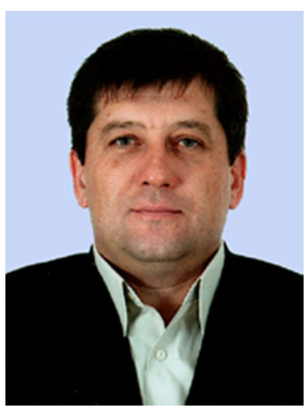

Oleh NALYVAIKO ${ }^{\circledR}$

Ph.D, Ass. Prof.
Alina
ORIESHKOVA $^{(}$
Lecturer $^{-}$

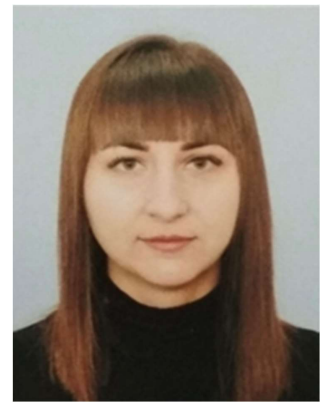

(Dnipropetrovsk State University of Internal Affairs)

\title{
GUARANTEES OF RIGHTS AND FREEDOM OF INTERNALLY DISPLACED PERSONS: THEORETICAL AND LEGAL CHARACTERISTICS
}

Олег Наливайко, Аліна Орєшкова. ГАРАНТІї ПРАВ І СВОБОД ВНУТРІШНЬО ПЕРЕМНЩЕНИХ ОСІБ: ТЕОРЕТИКО-ПРАВОВА ХАРАКТЕРИСТИКА. У стаТТі аКцеНТоваНО увагу, що внаслідок збройного конфлікту на територіях Донецької і Луганської областей, а також анексії Автономної Республіки Крим актуальним $є$ питання гарантування прав і свобод внутрішньо переміщених осіб. Показником рівня цивілізованості досягнутого суспільством і державою є ступінь реальності та гарантованості прав і свобод внутрішньо переміщених осіб. Зазначено, що основоположними принципами демократичної правової держави визнаються не лише закріплені у нормативно-правових актах права і свободи внутрішньо переміщених осіб. Дієвим показником рівня цивілізованості досягнутого суспільством і державою є передбачені гарантії їх захисту. Наголошено, що гарантування прав і свобод внутрішньо переміщених осіб $є$ основоположним чинником в політичній, економічній, культурній та інших сферах життєдіяльності суспільства. Зауважено, що на сьогодні не існує окремого комплексного системного дослідження 3 проблем гарантування прав і свобод внутрішньо переміщених осіб. Запропоновано авторську дефініцію визначення поняття «гарантії прав і свобод внутрішньо переміщених осіб». 3 метою повного та об'єктивного розкриття основних характеристик і особливостей визначення поняття «гарантії прав і свобод внутрішньо переміщених осіб», акцентовано увагу на найсуттєвіших його ознаках. Досліджено критерії класифікації видів гарантій прав і свобод людини і громадянина, які наведені в юридичній літературі. Запропоновано авторську систему гарантій прав і свобод внутрішньо переміщених осіб.

Ключові слова: внутрішньо переміщені особи, гарантії, загальносуспільні (загальносоціальні) гарантії, юридичні гарантії, нормативно-правові гарантії, організачійноправові (інститучійні) гарантії, реалізачія прав і свобод, забезпечення прав і свобод, захист $i$ охорона прав і свобод

Problem statement. Due to the armed conflict in the territories of Donetsk and Lugansk regions, as well as the annexation of the Autonomous Republic of Crimea, the issue of guaranteeing the rights and freedoms of internally displaced persons (hereinafter - IDPs) has become urgent. An indicator of the level of civility achieved by society and the state is the degree of actuality and guaranteeing of the rights and freedoms of internally displaced persons. Thus, the state cannot be considered democratic, social and legal in the absence of guarantees that ensure the effective realization of human and citizen rights and freedoms, including such categories of persons as internally displaced persons, and in case of their violation - safeguard, protection and restoration. The practical role and importance of guaranteeing the rights and freedoms of internally displaced persons is determined by the fact that they are fundamental factors in the political, economic, cultural and other spheres of society.

Analysis of publications in which solving this problem was started. In the scientific literature different aspects of guaranteeing the rights and freedoms of human and citizen were

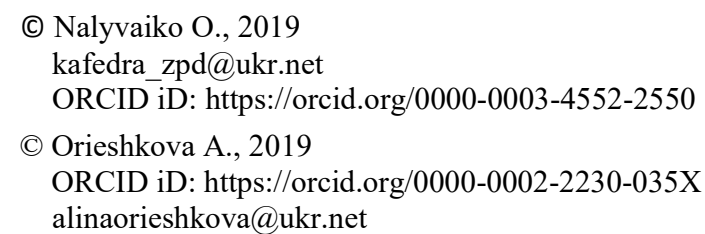


explored in their works by such scientists as: Yu. Barabash, M. Gurenko, O. Goncharenko, A. Kolodii, V. Kravchenko, O. Kushnirenko, S. Moroz, A. Oliinyk, O. Petryshyn, V. Pogorilko, P. Rabinovych, V. Rechytskyi, V. Tatsii, Y. Todyka, V. Shapoval, Y. Shemshuchenko and others. However, although there are developments in the legal literature on certain aspects of the protection of human and citizen rights and freedoms, there is currently no separate comprehensive study on the system of guaranteeing the rights and freedoms of internally displaced persons, which in turn actualizes the scientific clarification and justification of the said question.

The article's objective is to provide the author's definition of guarantee of the rights and freedoms of internally displaced persons on the basis of methodological analysis.

Basic content. According to Article 3 of the Constitution of Ukraine, a person, his life and health, honour and dignity, integrity and security are recognized in Ukraine as the highest social value. Human rights and freedoms and their guarantees determine the content and orientation of the state. The state is responsible to the person for its activities. Promoting and safeguarding human rights and freedoms is a state's primary responsibility. Article 21 guarantees that all people are free and equal in their dignity and rights. Human rights and freedoms are inalienable and inviolable. Article 64 of the Basic Law contains provisions according to which the constitutional rights and freedoms of the individual and the citizen cannot be restricted, except in cases provided by the Constitution of Ukraine [1]. In our country, the current condition of the legal status of internally displaced persons in various spheres of society shows: first, the imperfection; secondly, the imbalance of guaranteeing their rights and freedoms. One of the important features of law and order in society is to guarantee the rights and freedoms of IDPs. It should be emphasised that the creation of effective conditions for the exercise of the rights and freedoms of the studied category of persons is possible thanks to an effective guarantee system.

In the context of the above-mentioned, Yu. Todyka points out that, first and foremost, for successful implementation of the human and citizen rights and freedoms enshrined in the Constitution of Ukraine, favourable circumstances, consisting of many subjective and objective factors designed to ensure favourable conditions for the exercise of rights and freedoms, are needed [2, p. 182]. The guarantees of the rights and freedoms of internally displaced persons are interconnected and interdependent; collectively, they ensure their effective implementation, comprehensive safeguarding and protection.

According to A. Kolodii and A. Oliinyk, the mechanism of ensuring the exercise of rights and freedoms includes such elements as: guarantees of their exercise; legal elements of the mechanism of realisation; the process of practical implementation of opportunity and need for activity; conditions and factors of such process [3, p. 221]. Guarantees are one of the key elements of an effective legal mechanism for ensuring the rights and freedoms of internally displaced persons.

True to this is the opinion of scientists who say that in the absence of guarantees, the rights, freedoms and responsibilities of the individual and the citizen take the form of "statements of intent". After all, they become ordinary declarations that have no practical basis and, accordingly, no social value. In addition, guarantees are a kind of external mechanism of restriction of power, which always strives for self-expansion and strengthening of its presence in all spheres of human life [4, p. 85]. The above applies, in particular, to the rights and freedoms of the category of persons under investigation, since in order for them to function normally, effective guarantees should be put in place to protect IDPs in the exercise of their rights and freedoms.

The issue of ensuring human rights and freedoms, and effective guarantees for their implementation are reflected in the writings of many scholars, but despite this, research into the issue of guaranteeing the rights and freedoms of internally displaced persons becomes relevant. The very study of this issue led to the introduction of such a concept as the guarantees of the rights and freedoms of internally displaced persons into legal circulation. In this context, it is paramount to define the etymological meaning of the term "guarantee", which comes from the French word "garantie" and is translated as a security, pledge, condition that provides anything. In dictionaries, the concept of guarantee has the following interpretations: surety in something, securing something; provided for by law or agreement; legislatively enshrined means of protection of rights and freedoms of citizens, ways of their realization, as well as methods of protection of law and order, interests of society and the state; conditions that ensure the success of anything; responsibility for anything [5, p. 55]. The term "guarantees of the rights and freedoms of man and citizen" in modern encyclopedic literature is defined as conditions, means, 
ways that ensure the full and complete protection of the rights and freedoms of the individual. The concept of guarantee covers the whole set of objective and subjective factors aimed at the practical realization of rights and freedoms, and the elimination of possible obstacles to their full or proper exercise [6, p. 555]. Guarantees are the conditions, means, ways necessary for the effective exercise of the rights and freedoms of internally displaced persons, as well as the elimination of possible obstacles to their proper exercise.

As already mentioned, there is no single approach in the scientific literature to define the notion of guarantees of the rights and freedoms of internally displaced persons, so different scientific approaches are relevant, which is conditioned both by the scope and complexity of the concept under study.

As M. Vitruk notes, guarantees of human rights and freedoms are those conditions and means that ensure their actual implementation and reliable safeguarding (protection) for each person [7, p. 78]. M. Strogovych, believes that the guarantees are the legal means, norms of the law, the ways in which the rights of citizens are safeguarded and protected, their violations are terminated and eliminated, the violated rights are restored [8, p. 180]. Scholars consider the guarantees, conditions, ways and means by which the safeguarding and protection of rights and freedoms is exercised. A. Ivanov and V. Skobelkin considered guarantees in terms of their understanding as the means and methods by which the real exercise of democratic rights and freedoms of citizens is ensured [9, p. 108-109; 10, p. 10]. V. Kravchenko states that guarantees of human and citizen rights and freedoms are conditions and means that ensure the effective realization of the rights and freedoms of every person and citizen [11, p. 152]. In the abovementioned definitions the focus is on that the real enjoyment of democratic rights and freedoms is provided by means of guarantees. Soviet researchers have noted that guarantees of citizens' rights and freedoms are conditions, means, ways that ensure the full and comprehensive protection of human rights and freedoms. The notion of guarantee covers the whole set of objective and subjective factors aimed at the practical realization of rights and freedoms, the elimination of possible obstacles to their full or possible exercise [12, p. 41; 6, p. 555]. Thus, the rights and freedoms are realized by means of guarantees, and obstacles to their implementation are eliminated. According to A. Nikitin, guarantees of the rights and freedoms of a person are the obligations of the state to protect a person, to create legal, social and cultural conditions for the exercise of his rights and freedoms, as well as the activities of international and state human rights organizations $[13$, p. 76]. It is emphasised that guarantees are first and foremost a duty of the state; secondly, of the activities of international and national organizations for the protection of rights and freedoms. At the same time, S. Gusariev, A. Oliinyk, and O. Sliusarenko claim that guarantees of rights and obligations are appropriate conditions and means that contribute to the implementation of proclaimed rights and freedoms and fulfillment of obligations [14, p. 241]. K. Volynka substantiates a similar position in this regard [15, p. 18]. Under the guarantee of human and citizen rights and freedoms, scientists offer an understanding of the system of conditions and means that facilitate the practical exercise of rights and freedoms and the fulfillment of obligations.

According to the position of V. Pohorilko and V. Fedorenko, the guarantees of constitutional rights and freedoms of a person should be understood as a system of conditions and means, legal mechanisms for ensuring the proper realization of the rights and freedoms of a person and citizen defined by the Constitution and laws [16, p. 235]. In defining the concept, scientists focus on the system of conditions and means, the legal mechanisms through which rights and freedoms are realized.

The approach of M. Matuzov, O. Malko and A. Mordovets is meaningful in understanding the concept of guarantee, which states that guarantees are a socio-political and legal phenomenon, considering which the following points should be taken into account: cognitive, which allows to reveal the thematic theoretical knowledge about the object of their influence, to get practical knowledge about social and legal policy of the state; ideological, used by political authorities as a means of promoting democratic ideas inside and outside the country; practical, defined as a toolkit of jurisprudence, a prerequisite for satisfying person's social benefits. $[17$, p. 275]. The authors define guarantees as the preconditions, conditions, means and methods that make up the socio-economic, political, legal, organizational system and create personality opportunities for the exercise of the rights, freedoms and interests of the individual.

In his turn, O. Petryshyn interprets the guarantees of human and citizen rights and freedoms as a system of general (political, economic, spiritual, etc.) and special legal means and institutions aimed at creating conditions for the realization of human rights, as well as ensuring 
their comprehensive safeguarding and protection against violations [18, p. 456]. This approach is significant in the current context, as the content of the concept under study includes not only general guarantees but also special legal means and institutions.

The complexity of the content of the concept definition under consideration necessitates the classification of guarantees. In particular, today there is no consensus on the classification of guarantees of the rights and freedoms of internally displaced persons. In the scientific literature it is customary to distinguish between general and special (legal) guarantees. General guarantees stand for the totality of economic, political and other conditions that make rights real. Some scholars characterize such guarantees as "substantive guarantees of rights" [19, $\mathrm{p}$. $132 ; 20$, p. $76 ; 21$, p. 146]. They are also seen as a set of objective and subjective factors that make it possible to practically exercise the rights and freedoms of internally displaced persons, to eliminate probable causes and obstacles to their incomplete (improper) exercise, as well as to protect against violations. Special (legal) guarantees are legal means and methods, that is, provided by laws and other legal acts, with their help rights and freedoms of citizens are realized, safeguarded, protected, and violations of rights and freedoms are eliminated, violated rights are renewed [22, p. 132].

According to E. Bilozerova, the system of guarantees of rights and freedoms of a person is quite complex and extensive, it consists of such elements as: substantive and procedural guarantees; institutional and organizational guarantees; industry guarantees; international legal guarantees; legal liability [23, p. 217].

The system of guaranteeing human rights and freedoms, according to I. Rostovshchykov, consists of general conditions, as well as legal and other special means that ensure their lawful realization, and in necessary cases - protection [24, p. 50-58]. V. Pogorilko distinguishes two main groups of guarantees: general public (general social) and legal [25, p. 41]. At the same time, scholars share the general guarantees of political, economic, social and spiritual, where they are relevant social systems that have developed and function in society.

I. Magnovskyi, applying a narrow approach to the division of general guarantees, distinguishes political, economic and social guarantees [26, p. 13]. Together with the aforementioned guarantees, T. Slinko distinguishes spiritual, substantive and organizational guarantees. In particular, spiritual guarantees are the level of general and political and legal culture of citizens, their education, moral and psychological climate; political guarantees are a set of political measures and means by which the most optimal regime for the exercise of rights and freedoms is created; economic guarantees are a set of economic relations, the emergence and implementation of which promotes the exercise of constitutional rights and freedoms; substantive guarantees are specific objects and things by which the exercise of certain fundamental rights or freedoms is possible; organizational guarantees are systematic activity of the state and its bodies, officials, non-governmental organizations to create favorable conditions for the real enjoyment of citizens' rights and freedoms [27, p. 124]. The division of guarantees of human and citizen rights and freedoms into the general was traditional in the domestic legal literature of the Soviet and post-Soviet periods. In the current conditions, given the context of guaranteeing the rights and freedoms of internally displaced persons, it is impossible to consider the above classification as fundamental.

We should agree with I. Rostovshchykov's opinion, which states that in the sphere of rights and freedoms of citizens, their protection and implementation rely on the existence of appropriate general guarantees, without creating other guarantees and without taking additional measures it will lead to serious mistakes, which can have adverse effects, since any authority requires legal support. Legal guarantees include applicable principles, rules of law, other legal phenomena; in other words, it is a means of law envisaged to directly ensure the exercise and protection of subjective rights and freedoms [28]. This is the opinion of S. Bratus, who points out that general guarantees cannot directly guarantee the exercise of citizens' rights and freedoms. There is a need for specific legal guarantees without which legal rules cannot be put into practice [29]. Legal guarantees for the realization of human rights in society are the means enshrined in the law, which are the legal expression of the general conditions, and directly provide for the possibility of their legitimate implementation and protection [30]. V. Kopeichykov believed that legal guarantees of human rights and freedoms were a complex concept that extended to all spheres, forms and methods of activity of state and public organizations, as well as citizens, and encompassed the practical realization of the rights and legitimate interests of the individual [31]. By their very nature, legal guarantees are state-defined conditions, which are enshrined in the constitution, constitutional laws, as well as in sectoral legislation, and with which the internally displaced persons 
have the opportunity to exercise their rights and freedoms.

According to V. Fedorenko, there are two types of legal guarantees: normative legal, and organizational legal. Normative legal guarantees are represented by a system of constitutional law norms, which establish and consolidate the principles, forms, methods, mechanisms and procedures for the realization of constitutional rights and freedoms [32, p. 261]. As a coherent construction, normative legal guarantees of the rights and freedoms of internally displaced persons are represented by a system of interrelated substantive and procedural rules of law, which are objectively reflected in national and international legal acts and treaties. However, normative legal guarantees of the rights and freedoms of internally displaced persons can only be recognized as a constituting element of guaranteeing if it is a logically designed, purposeful and realistically valid system of legal rules.

Due to normative legal guarantees, the content of the rights and freedoms of internally displaced persons, the forms of their realization and the procedural procedures of safeguarding and protection are determined. Their feature is that they are provided with law-making and enforcement activities. The normative part of guaranteeing the rights and freedoms of internally displaced persons in Ukraine consists of substantive and procedural components. As stated in the judgement of the Constitutional Court of Ukraine of April 12, 2012 - No. 9-rp / 2012, the equality guaranteed by the Constitution of all people in their rights and freedoms means the need to provide them with equal legal opportunities, both substantive and procedural in nature, for the realization of equal, according to the content and scope, rights and freedoms [33]. The substantive legal component includes the rights and freedoms of IDPs, and procedural legal forms and means aimed at the realization, safeguarding and protection of the rights and freedoms of IDPs.

Organizational and legal guarantees are the socio-political institutions envisaged in normative and legal acts, which are entrusted with the respective functions and which are given certain powers to organize and carry out legal support of the realization, safeguarding and protection of the freedom of the individual and the citizen. According to the scientist, the main subjects of constitutional law, which are intended to provide organizational and legal guarantees, are: the people of Ukraine; territorial communities; public authorities and local self-government bodies, their officials; political parties; civil society and its institutions; citizens of Ukraine [34, p. 262]. In researching the guarantee of the rights and freedoms of internally displaced persons, the term "institutional mechanism" is used in scientific literature, which, in our opinion, is incorrect. Thus, to refer to entities that act jointly in the context of the protection of the rights and freedoms of internally displaced persons, it is advisable to use such identical concepts as "organizational and legal", "institutional and legal" system. In the context of the study of the classification of guarantees of the rights and freedoms of internally displaced persons, we will use the term "organizational and legal (institutional) guarantees". The main organizational and legal (institutional) guarantors of human and citizen rights and freedoms, including internally displaced persons in accordance with the Constitution of Ukraine, are the Verkhovna Rada of Ukraine (Article 92), the President of Ukraine (Article 102), and the Cabinet of Ministers of Ukraine (Article 116 ), the courts (Article 55), the Commissioner of the Verkhovna Rada of Ukraine for Human Rights (Article 55), the Prosecutor's Office (Article 131-1), local governments (Article 143), the bar association (Article 59), political parties and public organizations (Article 36), international judicial institutions and relevant bodies of international organizations of which Ukraine is a member or a party (Art. 55) [14, p. 41-45]. Having taken as a basis the provision of the Constitution of Ukraine to the structure of organizational and legal (institutional) guarantors authorized to enforce the rights and freedoms of internally displaced persons, we can refer to the activities of such entities as: the Verkhovna Rada of Ukraine and its institutions; President of Ukraine and his institutions; the Cabinet of Ministers of Ukraine, as well as central and local executive authorities; the Constitutional Court of Ukraine and the courts of general jurisdiction; local governments; the prosecutor's office; the bar association; free legal aid centres; support services for victims (general and specialized); civil society institutions; international and national specialized agencies, representative offices, funds accredited in Ukraine; enterprises, institutions and organizations of state and private ownership, etc.

Effective development of the system of guaranteeing the rights and freedoms of internally displaced persons is possible due to the harmonization of the functioning of the organizational and legal (institutional) components.

At the same time, S. Kashkin proposes to divide the guarantees of human and citizen rights and freedoms into domestic (national) and international law [34]. The former include 
judicial and extrajudicial domestic guarantees, and international legal guarantees are divided into universal (provided by the UN and specialized units) and regional (provided at the regional international level) [33, p. 453]. Universal protection is exercised within the activities of the UN and its specialized agencies (for example, the UN Commission on Human Rights, which has today been replaced by the New Council), which has the responsibility to monitor the human rights situation and assist individual states in improving their legislation [35]) and regional within the framework of the inter-American, European and African systems. The European system based on the European Convention for the Protection of Human Rights and Fundamental Freedoms is considered to be the most perfect [36]. Domestic (national) guarantees, which are provided by both judicial and extrajudicial bodies, protect the rights and freedoms of internally displaced persons in a particular state, and international guarantees are the actions of the entire human community. However, the division of guarantees of the rights and freedoms of internally displaced persons into domestic (national) and international law is inappropriate because they are part of the content of the organizational and legal (institutional) components.

The given classifications of the types of guarantees of the rights and freedoms of the person and the citizen can be supplemented by other criteria that will allow to deepen the basic knowledge about the variety of legal nature of the guarantees of the rights and freedoms of internally displaced persons.

Conclusions. On the basis of the stated scientific points of view regarding the understanding of the definition of guarantees of the rights and freedoms of man and citizen, we believe that the guarantees of the rights and freedoms of internally displaced persons are a set of general and specially legal conditions, means and methods, as well as institutions through which effective realization of the rights and freedoms of internally displaced persons and, in case of violation, the possibility of their protection and restoration is ensured.

However, the nature of the guarantees of the rights and freedoms of internally displaced persons cannot be known without analyzing their features. At the same time, in order to fully and objectively reveal the main characteristics and features of this complex in its content and multifaceted manifestations of the phenomenon, it is necessary to focus on its most essential features, among which we can distinguish the following:

first, the guarantees of the rights and freedoms of internally displaced persons have the form of a complex system, which is an aggregate of general (political, economic, etc.) and specially legal means and institutions that are inextricably linked and interacting;

second, the guarantees of the rights and freedoms of internally displaced persons are of a state nature. That is, they are created by it, expressing a measure of freedom, equality and justice that is embodied by recognizing in the world community and ensuring that the rights and freedoms of one person limit the rights and freedoms of another. Also, the enforcement of guarantees is supported and secured by the power of state influence, in particular through the use of coercive measures;

third, the guarantees of the rights and freedoms of internally displaced persons are reflected at the level of the relevant national and international legal acts, which confers upon them such properties as generality, universality and legal protection;

fourth, the guarantees of the rights and freedoms of internally displaced persons are universal and continuous. Thus, they mostly operate permanently and extend to the entire territory of the state;

fifth, the state and level of development of the main spheres of public life reflect precisely the guarantees of the rights and freedoms of internally displaced persons, because by means of their analysis it is possible to form an idea of the priorities of state policy, of the political, economic and social atmosphere in a country that is one on the level of development of the national legal system;

sixth, the guarantees of the rights and freedoms of internally displaced persons are real and appropriate, because they are conditions and factors that exist in an objective reality and make the process of realizing the rights, freedoms and legitimate interests clear, free, unimpeded and secure.

The structure of the system of guaranteeing the rights and freedoms of internally displaced persons is proposed to include: social, normative and legal, and institutional (organizational and legal) components. General social guarantees include political, economic, social and spiritual guarantees. Organizational and legal (institutional) guarantees are represented by the activities of such entities as: the Verkhovna Rada of Ukraine and its institutions; President of Ukraine and its institutions; the Cabinet of Ministers of Ukraine, as well as central and local 
executive authorities; the Constitutional Court of Ukraine and the courts of general jurisdiction; local governments; the prosecutor's office; the bar association; free legal aid centres; support services for victims (general and specialized); civil society institutions; international and national specialized agencies, representative offices, funds accredited in Ukraine; enterprises, institutions and organizations of state and private ownership, etc. Legal guarantees provided by interrelated substantive and procedural norms of law, which are objectively reflected in the hierarchical system of national and international legal acts and treaties. However, it should be noted that the aforementioned system of guarantees needs substantial refinement, in particular, that further scientific analysis and study are needed to provide theoretical and practical guidance for further improvement. The guarantees of the rights and freedoms of internally displaced persons are a complex, structured, dynamic, integrated system that, through the social, normative, and institutional (organizational and legal) components, purposefully ensures and enforces the rights and freedoms of IDPs in all spheres of public life.

References:

1. Конституція України від 28.06.1996 р. Відомості Верховної Ради України. 1996. № 30. Ст. 141.

2. Тодыка Ю.Н., Тодыка О.Ю. Конституционно-правовой статус человека и гражданина в Украине. Київ: Концерн «Видавничий Дім «Ін Юре», 2004. С. 368.

3. Колодій А.М., Олійник А.Ю. Права людини і громадянина в Україні: навч. посібник. Київ: Юрінком Інтер, 2003. 336 с.

4. Годованець В.Ф. Конституційне право України: конспект лекцій. 2-ге вид., стер. Київ: МАУП, 2001. $216 \mathrm{c.}$

5. Великий тлумачний словник сучасної української мови (з дод. і допов.) / уклад. і голов. ред. В.Т. Бусел. Київ ; Ірпінь : ВТФ «Перун», 2005. 1728 с.

6. Юридична енциклопедія: в 6 т. / редкол.: Ю.С. Шемшученко та ін. Київ: Укр. Енциклопедія, 1998-2004. Т. 1: А-Г. 1988. 672 с.

7. Витрук Н.В. Основы теории правового положения личности в социалистическом обществе. М. : Наука, 1979. 229 с.

8. Строгович М.С. Основные вопросы советской социалистической законности. М.: Наука, 1966. $271 \mathrm{c.}$

9. Иванов А.П. Гарантии конституционных прав советских граждан. Учен. записки Саратов. юрид. ин-та им. Д. И. Курского. 1968. Вып. XVII. Кн.1. С. 11-15.

10. Скобелкин В.Н. Юридические гарантии трудовых прав рабочих и служащих / Скобелкин В.Н. М.: Юрид. лит., 1969. 183 с.

11. Кравченко В.В. Конституційне право України: навч. посіб. ; вид. 6-е, виправл. та доповн. Київ: Атіка, 2009. 608 с.

12. Малеин Н.С. Повышение роли закона в охране личных и имущественных прав граждан. Сов. государство и право. 1977. № 6. С. 41-46.

13. Словарь-справочник по праву / сост. А. Ф. Никитин. М. : Акалис, 1995. 140 с.

14. Гусарєв С.Д., Олійник А.Ю., Слюсаренко О.Л. Теорія права і держави: навч. посіб. Київ: Правова єдність, 2008. 270 с.

15. Волинка К.Г. Правовий статус особи та гарантії реалізації прав і свобод за Конституцією України. Київ: НПУ ім. М.П. Драгоманова, 1998. 34 с.

16. Погорілко В.Ф., Федоренко В.Л. Конституційне право України: підручник / за заг. ред. проф. В.Л. Федоренка. 3-є вид., перероб. і доопр. ; передм. проф. В.В. Коваленка. Київ: КНТ ; Видавництво Ліра-К, 2011. $532 \mathrm{c.}$

17. Матузов Н.А., Малько А.В. Теория государства и права: курс лекций. М. : Юрист, 1977. $672 \mathrm{c}$.

18. Ц Цвік М.В., Петришин О.В., Авраменко Л.В. Загальна теорія держави і права: підруч. для студ. юрид. вищ. навч. / за ред. д-ра юрид. наук., проф. акад. АПрН України М.В. Цвіка, д-ра юрид. наук., проф. акад. АПрН України О.В. Петришина. Харків: Право, 2011. 584 с.

19. Витрук Н.В. Основы теории правового положения личности в социалистическом обществе. М. : Наука, 1979. 229 с.

20. Шрамко Ю.Т. Конституційне право на правову допомогу в Україні: актуальні питання законодавчого регулювання: дис ... канд. юрид. Наук : 12.00 .02 / Національна академія наук України, Інститут держави і права ім. В.М. Корецького. Київ, 2016. 186 с.

21. Фарбер И.Е., Ржевский В.А. Вопросы теории советского конституционного права. Вып. 1. Саратов : Приволж. кн. изд-во , 1967. 319с.

22. Конституційне право України : підруч. для студ. вищ. навч. закл. / [Л.К. Байрачна, Ю.Г. Барабаш, Ф.В. Веніславський та ін.] ; за ред. В.П. Колісника, Ю.Г. Барабаша. Харків: Право, 2008. $416 \mathrm{c}$.

23. Волинка К.Г. Теорія держави і права : навч. посібник. Київ.: МАУП, 2003. 240 с.

24. Ростовщиков И.В. Обеспечение прав и свобод личности в СССР: Вопросы теории. Саратов: Изд. Саратовского ун-та, 1988. 117 с.

25. Нова Конституція України: Огляд, коментарі і текст Основного Закону / За ред. В.Ф. Погорілка. Київ: Правова держава, 1997. 156 с. 
26. Магновський І.Й. Гарантії прав і свобод людини та громадянина в праві України (теоретико-правовий аспект) : дис... канд. юрид. наук : 12.00 .02 / Нац. акад. внутр. справ України. Київ, 2003. 221 с.

27. Кушніренко О.Г, Слінько Т.М. Конституційне право України у запитаннях i відповідях : навч. посібник. Харків : Майдан, 2012. 330 с.

28. Ростовщиков И.В. О структуре юридических гарантий обеспечения прав человека. Весник Волгоградского государственного университета. 2008. № 10. С. 37-43.

29. Братусь С.Н. Юридическая ответственность и законность: очерк истории. М. : Юр. лит., 1976.216 с.

30. Гайнетдинов А.Н. Конституционные гарантии защиты прав и свобод граждан от неправомерных действи (бездействий) субъектов правоохранительной системы Российской Федерации: автореф. дис. ... канд. юрид. наук : 12.00 .02 / Северо-Кавказская академия государственной службы. Ростов-на-Дону, 2004. 21 с.

31. Копейчиков В.В. Реализация субъективных прав граждан. Сов. государство и право. 1984. № 3. C. 22-27.

32. Федоренко В.Л. Конституційне право України : підруч. / До 20-ї річниці Конституції України та 25-ої річниці незалежності України. Київ : Видавництво Ліра-К, 2016. 615 с.

33. Рішення Конституційного Суду України у справі за конституційним зверненням громадянина Трояна Антона щодо офіційного тлумачення положень статті 24 Конституції України (справа про рівність сторін судового процесу) : від 12.04 .2012 р., № 9-рп/2012. Вісник Конституиійного суду Украӥни. 2012. № 3. Ст. 41.

34. Шукліна Н.Г. Конституційно-правове регулювання прав i свобод людини i громадянина в Україні (проблеми теорії і практики): монографія. Київ: Центр учбової літератури, 2005. C. $332-339$

35. Веб-сайт Уповноваженого Верховної Ради України 3 прав людини: http://www.ombudsman.gov.ua.

36. Маклаков В.В. Основы теории конституции. Конституиионное (государственное) право зарубежных стран: в 4 т. / отв. ред. Б.А. Страшун. Т. 1-2. Часть Общая. М.: БЕК, 2000. C. $44-45$.

Received to editorial office 11.12.2019

1. Konstytutsiya Ukrayiny [The Constitution of Ukraine] vid 28.06.1996 r. Vidomosti Verkhovnoyi Rady Ukrayiny. 1996. № 30. St. 141. [in Ukr.]

2. Todyka, Yu. N., Todyka, O. Yu. (2004) Konstytutsyonno-pravovoy status cheloveka y hrazhdanyna $v$ Ukrayne [The constitutional and legal status of the man and the citizen in Ukraine]. Kyiv: Kontsern «Vydavnychyy Dim «In Yure», 368 s. [in Russ.]

3. Kolodiy, A. M., Oliynyk, A. Yu. (2003) Prava lyudyny i hromadyanyna v Ukrayini [Human and citizen rights in Ukraine]: navch. posibnyk. Kyiv: Yurinkom Inter, 336 s. [in Ukr.]

4. Hodovanets', V.F. (2001) Konstytutsiyne pravo Ukrayiny [Constitutional Law of Ukraine]: konspekt lektsiy. 2-he vyd., ster. Kyyiv: MAUP, 216 s. [in Ukr.]

5. Velykyy tlumachnyy slovnyk suchasnoyi ukrayins'koyi movy [Big explanatory dictionary of modern Ukrainian (with additions and supplements)] (z dod. i dopov.) / uklad. i holov. red. V.T. Busel. Kyiv ; Irpin' : VTF «Perun», 2005. 1728 s. [in Ukr.]

6. Yurydychna entsyklopediya [Legal Encyclopedia]: v 6 t. / redkol.: Yu.S. Shemshuchenko ta in. Kyiv: Ukr. Entsyklopediya, 1998-2004. T. 1: A-H. 1988. 672 s. [in Ukr.]

7. Vitruk N.V. (1979) Osnovy teorii pravovogo polozheniya lichnosti v sotsyalisticheskom obshchestve [Fundamentals of the theory of the legal position of the individual in socialist society]. M. : Nauka, 229 s. [in Russ.]

8. Strohovich, M. S. (1966) Osnovnyye voprosy sovetskoy sotsyalisticheskoy zakonnosti [The main issues of Soviet socialist legitimacy]. M.: Nauka,. 271 s. [in Russ.]

9. Ivanov, A.P. (1968) Garantii konstitutsyonnykh prav sovetskikh grazhdan [Guarantees of the constitutional rights of Soviet citizens]. Uchen. zapisky Saratov. yurid. in-ta im. D. I. Kurskogo. Vyp. XVII. Kn.1. S. 11-15. [in Russ.]

10. Skobelkin, V.N. (1969) Yuridicheskiye garantii trudovykh prav rabochykh i sluzhashchikh [Legal guarantees of labor rights of workers and employees]. M.: Yur. lit., 183 s. [in Russ.]

11. Kravchenko, V. V. (2009) Konstytutsiyne pravo Ukrayiny [Constitutional Law of Ukraine]: navch. posib. ; vyd. 6-e, vypravl. ta dopovn. Kyiv: Atika, 608 s. [in Ukr.]

12. Malein, N.S. (1977) Povysheniye roli zakona v okhrane lichnykh i imushchestvennykh prav grazhdan [Increasing the role of the law in protecting the citizens' personal and property rights]. Sov. hosudarstvo y pravo. № 6. S. 41-46. [in Russ.]

13. Slovar'-spravochnik po pravu [Law Dictionary] / sost. A. F. Nikitin. M. : Akalys, 1995. $140 \mathrm{~s}$.

14. Husaryev, S. D., Oliynyk, A. Yu., Slyusarenko, O. L. (2008) Teoriya prava i derzhavy [Theory of Law and State]: navch. posib. Kyyiv: Pravova yednist', 270 s. [in Ukr.]

15. Volynka, K. H. (1998) Pravovyy status osoby ta harantiyi realizatsiyi prav i svobod za Konstytutsiyeyu Ukrayiny [Legal status of person and guarantees of rights and freedoms]. Kyyiv: NPU im. M.P. Drahomanova, 34 s. [in Ukr.]

16. Pohorilko, V. F., Fedorenko, V. L. (2011) Konstytutsiyne pravo Ukrayiny [Constitutional Law of Ukraine]: pidruchnyk / za zah. red. prof. V.L. Fedorenka. 3-ye vyd., pererob. i doopr. ; peredm. 
prof. V.V. Kovalenka. Kyiv: KNT ; Vydavnytstvo Lira-K, 532 s. [in Ukr.]

17. Matuzov, N. A., Mal'ko, A. V. (1977) Teoriya gosudarstva i prava [Theory of State and Law]: kurs lektsyy. M. : Yurist, 672 s. [in Russ.]

18. Tsvik, M. V., Petryshyn, O. V., Avramenko, L. V. (2011) Zahal'na teoriya derzhavy i prava [General theory of state and law]: pidruch. dlya stud. yuryd. vyshch. navch. / za red. d-ra yuryd. nauk., prof. akad. APrN Ukrayiny M.V. Tsvika, d-ra yuryd. nauk., prof. akad. APrN Ukrayiny O.V. Petryshyna. Kharkiv: Pravo, 584 s. [in Ukr.]

19. Vitruk, N. V. (1979) Osnovy teorii pravovogo polozheniya lichnosti v sotsyalisticheskom obshchestve [Fundamentals of the theory of the legal position of the individual in socialist society]. M. : Nauka, 229 s. [in Russ.]

20. Shramko, Yu. T. (2016) Konstytutsiyne pravo na pravovu dopomohu v Ukrayini [Constitutional Right to Legal Assistance in Ukraine: Current Issues in Legislative Regulation]: aktual'ni pytannya zakonodavchoho rehulyuvannya: dys ... kand. yuryd. Nauk : 12.00.02 / Natsional'na akademiya nauk Ukrayiny, Instytut derzhavy i prava im. V.M. Korets'koho. Kyiv, 186 s. [in Ukr.]

21. Farber I. E., Rzhevskyy V. A. (1967) Voprosy teorii sovetskogo konstgtutsyonnogo prava [Issues of the theory of Soviet constitutional law]. Vyp. 1. Saratov : Privolzh. kn. yzd-vo, 319 s. [in Russ.]

22. Konstytutsiyne pravo Ukrayiny [Constitutional Law of Ukraine] : pidruch. dlya stud. vyshch. navch. zakl. / [L.K. Bayrachna, YU.H. Barabash, F.V. Venislavs'kyy ta in.] ; za red. V.P. Kolisnyka, YU.H. Barabasha. Kharkiv: Pravo, 2008. 416 s. [in Ukr.]

23. Volynka, K. H. (1988) Teoriya derzhavy i prava [Theory of State and Law]: navch. posibnyk. Kyiv.: MAUP, 2003. 240 s. 24. Rostovshchykov Y.V. Obespechenye prav y svobod lychnosty v SSSR: Voprosy teoryy. Saratov: Yzd. Saratovskoho un-ta, 117 s. [in Ukr.]

25. Nova Konstytutsiya Ukrayiny: Ohlyad, komentari i tekst Osnovnoho Zakonu [New Constitution of Ukraine: Review, Commentary and Text of the Fundamental Law] / Za red. V.F. Pohorilka. Kyiv: Pravova derzhava, 1997. $156 \mathrm{~s}$. [in Ukr.]

26. Mahnovs'kyy, I. Yo. (2003) Harantiyi prav i svobod lyudyny ta hromadyanyna v pravi Ukrayiny (teoretyko-pravovyy aspekt) [Guarantees of human and citizen's rights and freedoms in the law of Ukraine (theoretical and legal aspect)]: dys... kand. yuryd. nauk : 12.00.02 / Nats. akad. vnutr. sprav Ukrayiny. Kyiv,. $221 \mathrm{~s}$. [in Ukr.]

27. Kushnirenko, O. H, Slin'ko, T. M. (2012) Konstytutsiyne pravo Ukrayiny u zapytannyakh i vidpovidyakh [The Constitutional Law of Ukraine in Questions and Answers]: navch. posibnyk. Kharkiv : Maydan, 330 s. [in Ukr.]

28. Rostovshchykov, I. V. (2008) O strukture yuridicheskikh garantiy obespecheniya prav cheloveka [On the structure of legal guarantees for human rights]. Vesnyk Volhohradskoho hosudarstvennoho unyversyteta. № 10. S. 37-43. [in Russ.]

29. Bratus', S. N. (1976) Yuridycheskaya otvetstvennost' i zakonnost': ocherk istorii [Legal Responsibility and Legality: An Outline of History]. M. : Yur. lit., 216 s. [in Russ.]

30. Gaynetdinov, A. N. (2004) Konstitutsyonnyye garantii zashchity prav i svobod grazhdan ot nepravomernykh deystviy (bezdeystviy) sub"ektov pravookhranytel'noy sistemy Rossiyskoy Federatsyi [Constitutional guarantees for the protection of the rights and freedoms of citizens from unlawful actions (omissions) of the subjects of the law enforcement system of the Russian Federation]: avtoref. dys. ... kand. yuryd. nauk : 12.00.02 / Severo-Kavkazskaya akademyya hosudarstvennoy sluzhby. Rostov-naDonu, 21 s. [in Russ.]

31. Kopeychykov, V. V. (1984) Realyzatsyya sub"ektyvnykh prav grazhdan [Realization of subjective citizens' rights. Sov. hosudarstvo i pravo. № 3. S. 22-27. [in Russ.]

32. Fedorenko, V. L. (2016) Konstytutsiyne pravo Ukrayiny [Constitutional Law of Ukraine]: pidruch. / Do 20-yi richnytsi Konstytutsiyi Ukrayiny ta 25-oyi richnytsi nezalezhnosti Ukrayiny. Kyiv : Vydavnytstvo Lira-K,. 615 s. [in Ukr.]

33. Rishennya Konstytutsiynoho Sudu Ukrayiny u spravi za konstytutsiynym zvernennyam hromadyanyna Troyana Antona shchodo ofitsiynoho tlumachennya polozhen' statti 24 Konstytutsiyi Ukrayiny (sprava pro rivnist' storin sudovoho protsesu) [Decision of the Constitutional Court of Ukraine in the case on the constitutional request of a citizen of Troyan Anton regarding the official interpretation of the provisions of Article 24 of the Constitution of Ukraine (Case of Equality of Parties to the Trial)]: vid 12.04.2012 r., № 9-rp/2012. Visnyk Konstytutsiynoho sudu Ukrayiny. 2012. № 3. St. 41. [in Ukr.]

34. Shuklina N.H. Konstytutsiyno-pravove rehulyuvannya prav i svobod lyudyny i hromadyanyna v Ukrayini (problemy teoriyi i praktyky) [The constitutional and legal regulation of human and citizen's rights and freedoms in Ukraine (problems of theory and practice)]: monohrafiya. Kyiv: Tsentr uchbovoyi literatury, 2005. S. 332-339. [in Ukr.]

35. Veb-sayt Upovnovazhenoho Verkhovnoyi Rady Ukrayiny z prav lyudyny [Website of the Ombudsman of Ukraine:]: http://www.ombudsman.gov.ua. [in Ukr.]

36. Maklakov, V. V. (2000) Osnovy teoryy konstitutsyi [Fundamentals of the theory of constitution]. Konstitutsyonnoye (gosudarstvennoye) pravo zarubezhnykh stran: v 4 t. / otv. red. B. A. Strashun. T. 1-2. Chast' Obshchaya. M.: BEK,. S. 44-45. [in Russ.]

\section{Summary}

The article emphasises that guaranteeing the rights and freedoms of internally displaced persons is a topical issue due to the armed conflict in the territories of Donetsk and Luhansk regions, as well as the annexation of the Autonomous Republic of Crimea. It is noted that not only rights and freedoms of internally displaced persons enshrined in the legal acts are recognized as the fundamental principles of a dem- 
ocratic rule of law. An effective indicator of the level of civilization achieved by society and the state are the ensured guarantees of their protection. It is highlighted that guaranteeing the rights and freedoms of internally displaced persons is a fundamental factor in political, economic, cultural and other spheres of life of society. It is noted that at present there is no separate comprehensive systematic research on the problems of guaranteeing the rights and freedoms of internally displaced persons. The author's definition of "guarantees of the rights and freedoms of internally displaced persons" is proposed. In order to fully and objectively disclose the main characteristics and peculiarities of defining the concept of "guarantees of the rights and freedoms of internally displaced persons", attention is paid to its most essential features. The criteria of classification of the types of guarantees of human and citizen rights and freedoms, which are given in the legal literature, are investigated. The author's system of guarantees of the rights and freedoms of internally displaced persons is offered.

Keywords: internally displaced persons, guarantees, general public (general social) guarantees, legal guarantees, normative legal guarantees, organizational and legal (institutional) guarantees, realization of rights and freedoms, securing rights and freedoms, safeguarding and protection of rights and freedoms.

UDC $342.7(351.84)$

DOI: $10.31733 / 2078-3566-2019-5-100-105$

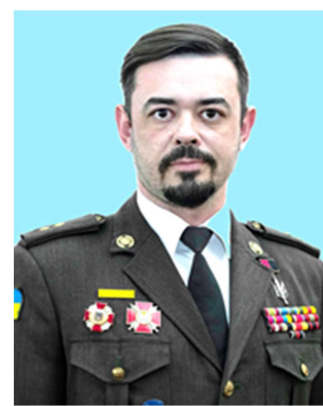

Kyrylo NEDRYA ${ }^{\complement}$

Ph.D

\author{
Nataliya \\ DAVYDOVA ${ }^{\odot}$ \\ Lecturer
}

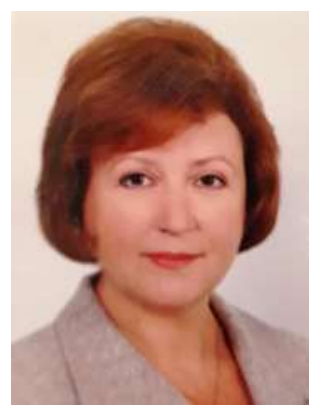

(Dnipropetrovsk State University of Internal Affairs)

\section{STATE SOCIAL GUARANTEES OF WAR VETERANS AROUND THE WORLD: DERIVATION AND FORMATION BEFORE THE FIRST WORLD WAR (TAKING INTO CONSIDERATION THE USA, UNITED KINGDOM, FRANCE AND GERMANY EXPERIENCE)}

Кирило Недря, Наталія Давидова. ДЕРЖАВНІ СОЦІАЛЬНІ ГАРАНТІї ВЕТЕРАНАМ ВІЙНИ У СВІТІ: ВИЗНАЧЕННЯ ТА ФОРМУВАННЯ ДО ПЕРЕШОӤ СВІТОВОЇ ВІЙНИ (ДОВІД США, ВЕЛИКОБРИТАНІЇ, ФРАНЦІЇ ТА НІМЕЧЧИНИ). Аналізується історія становлення i розвитку системи надання соціально-правових гарантій учасникам бойових дій на прикладі чотирьох держав: Великобританії, Франції, Німеччини та Сполучених Штатів Америки, у період до 1914 року. Зазначені країни були обрані не випадково. Критерієм добору виступила військова активність, яка була більш ніж високою у порівнянні 3 іншими державами, що пояснюється статусом колоніальних імперій. США ж були взяті як держава, яка була утворена саме у боротьбі проти колоніалізму. Було виявлено чітку взаємозалежність предмету дослідження від участі у бойових діях армій зазначених держав та чітку соціально-економічну спрямованість державних гарантій ветеранам, що пояснюється намаганням 3 боку державних структур зменшити власний соціальний тягар у вигляді зазначеної категорії. При цьому ж, практично не приділялася увага соціальній та психологічній адаптації після війни.

Зроблено висновок, що у тенденціях розвитку системи соціального забезпечення для учасників бойових можна чітко виокремити низку закономірностей. Першою 3 них $\epsilon$ те, що незважаючи на цивілізаційний розвиток та державну приналежність, ключовою соціальною гарантією розглядалося виділення земельної ділянки, що, з одного боку, несло символічний зміст - за землю і воювали, а з іншого - суто практичний: вона мала велику цінність та розглядалася як база для самозабезпечення ветераном. А другою закономірністю $є$ циклічність розвитку соціально-

(C) Nedrya K., 2019

ORCID iD: https://orcid.org/0000-0002-9370-1900

k.nedrya@gmail.com

(C) Davydova N., 2019

k_mp@dduvs.in.ua 